\title{
PREVALENSI DAN FAKTOR YANG BERHUBUNGAN DENGAN NYERI BAHU PADA TENAGA KEPERAWATAN DI RUMAH SAKIT ATMA JAYA
}

\author{
Aurelia Vania, Jimmy Barus
}

Departemen Neurologi, FKIK Unika Atma Jaya/RS Atma Jaya, Jakarta, Indonesia

Diterima 26 Februari 2020

Disetujui 11 Juni 2020

Publikasi 15 Juni 2020

Korespondensi: aureliavania.aj@gmail.com

\section{ABSTRAK}

Latar Belakang: Perawat berisiko mengalami nyeri bahu yang dapat mempengaruhi kinerja, produktivitas, dan aktivitas sehari-hari.

Tujuan: Untuk mengetahui karakteristik dan faktor risiko nyeri bahu pada tenaga keperawatan di RS Atma Jaya.

Metode: Studi potong lintang ini dilakukan pada perawat di RS Atma Jaya pada bulan Juli-Agustus 2019. Kuesioner digunakan sebagai instrumen.

Hasil: Responden terdiri dari 98 wanita dan 12 pria dengan rerata usia 29,6 \pm 7 tahun. Kejadian nyeri bahu 1 tahun terakhir 47,3\% dengan rerata Numeric Rating Scale $3,3 \pm 1,4$ dan $76,9 \%$ timbul setelah bekerja. Shift malam menjadi faktor protektif nyeri bahu ( $R O=0,3 ; 95 \%$ IK 0,1-0,6; $p=0,003$ ).
Cara merujuk artikel ini: Vania (et al). 2020. Prevalensi dan Faktor yang Berhubungan dengan Nyeri Bahu pada Tenaga Keperawatan di Rumah Sakit Atma Jaya. Callosum Neurology Journal 3(2): 78-85. DOI: https://doi.org/10.29342/cnj.v3i2.112

Usia $>30$ tahun, lama kerja $>5$ tahun, nyeri area tubuh lain, menarik atau menopang beban $>10 \mathrm{~kg}$, dan aktivitas dengan posisi lengan $\mathrm{di}$ atas bahu merupakan faktor risiko bermakna ( $p \leq 0.05$ ). Regresi logistik menunjukkan nyeri area tubuh lain sebagai faktor risiko paling bermakna ( $\mathrm{RO}=4,9 ; 95 \%$ IK 1,7-14,4; $p=0,003)$.

Simpulan: Nyeri area tubuh lain merupakan faktor paling berperan untuk nyeri bahu. Faktor lainnya adalah usia >30 tahun, lama kerja $>5$ tahun, menarik atau menopang beban berat, dan aktivitas dengan posisi lengan di atas bahu. Shift malam merupakan faktor protektif kejadian nyeri bahu.

Kata Kunci: Faktor risiko, Nyeri bahu, Perawat

\begin{abstract}
Background: Nurses have high risk of shoulder pain that affects ability and productivity or daily activities.

Purpose: To determine features and risk factors of shoulder pain in nurses.

Method: This cross-sectional study involved Atma Jaya Hospital nurses in July-August 2019. Questionnaire was used as tool.

Result: This study involved 98 women and 12 men with average age of $29.6 \pm 7$ years. Among $47.3 \%$ respondents experienced shoulder pain in the past 1 year with average NRS of $3.3 \pm 1.4$ and $76.9 \%$ of pain appeared after work. Nightshift was protective factor for shoulder pain $(\mathrm{OR}=0,3 ; 95 \% \mathrm{Cl} 0,1-0,6 ; \mathrm{p}=0,003)$. Age $>30$ years, length of work $>5$ years, pain in other body
\end{abstract}

areas, activity of pulling or supporting a load $>10 \mathrm{~kg}$, and arms over shoulder are significant risk factors $(p \leq 0.05)$. Logistic regression showed pain in other body areas as the most significant one $(O R=4,9$; $95 \% \mathrm{Cl} 1,7-14,4 ; \mathrm{p}=0,003)$.

Conclusion: Pain in other body areas is the most important factor for shoulder pain. Other are age $>30$ years, length of work $>5$ years, activity of pulling or bearing heavy loads, and working with arms above the shoulder. Nightshift is a protective factor for shoulder pain. Keywords: risk factors, shoulder pain, nurse 


\section{Latar Belakang}

Gangguan muskuloskeletal seperti nyeri leher, nyeri bahu, nyeri punggung bawah merupakan masalah umum yang sering dijumpai sehari-hari dan mempunyai angka prevalensi tinggi di seluruh dunia. ${ }^{1}$ Perawat merupakan profesi dengan risiko tinggi mengalami nyeri muskuloskeletal. ${ }^{1-2}$ Perawat memiliki tugas yang melibatkan berbagai aktivitas, mempunyai jam kerja panjang, terkadang memiliki lebih dari satu pekerjaan, dan tidak mendapatkan cukup waktu untuk beristirahat atau tidur. Lingkungan kerja perawat terkadang juga tidak mendukung secara ergonomik. ${ }^{2-3}$

Bahu merupakan salah satu dari area anatomi muskuloskeletal dengan keluhan nyeri paling sering pada populasi perawat. ${ }^{2,4-5}$ Prevalensi nyeri bahu memiliki angka kejadian lebih rendah daripada nyeri punggung bawah, tetapi nyeri pada area ini merupakan salah satu penyebab penting morbiditas penderita. ${ }^{6}$ Adanya gangguan rentang gerak akibat nyeri dapat mempengaruhi secara signifikan kemampuan dan produktivitas perawat dalam bekerja yang akhirnya dapat mempengaruhi keselamatan pasien dalam praktek klinis. ${ }^{4}$ Studi di New Zealand melaporkan insiden nyeri bahu sebesar $25 \%$ dengan $61 \%$ bersifat persisten atau rekuren, $10 \%$ menghambat pekerjaan, dan 14\% mengganggu aktivitas fungsional sehari-hari. ${ }^{1}$ Studi lain melaporkan nyeri bahu merupakan penyebab signifikan absensi perawat sementara. Nyeri pada area ekstremitas superior merupakan penyebab signifikan gangguan dalam melakukan pekerjaan rumah. 3,5

Penyebab nyeri bahu bersifat multifaktorial oleh karena itu membutuhkan evaluasi faktor risiko yang meliputi faktor yang berpotensi menyebabkan nyeri bahu. ${ }^{7-8}$ Studi mengenai faktor risiko gangguan muskuloskeletal terutama nyeri punggung bawah pada perawat sudah banyak dilakukan, tetapi studi yang terfokus pada faktor risiko nyeri bahu masih jarang dilakukan. Oleh karena pengaruh signifikan nyeri bahu terhadap kemampuan bekerja dan produkivitas, peneliti merancang penelitian ini untuk mengukur prevalensi dan gambaran karakteristik nyeri bahu secara khusus pada tenaga perawat di RS Atma Jaya. Selain itu, penelitian ini memiliki tujuan utama untuk menilai kondisi yang menjadi faktor risiko yang berpengaruh pada timbulnya nyeri bahu pada tenaga perawat. Identifikasi dan perencanaan program untuk meminimalisir paparan faktor risiko saat bekerja merupakan komponen penting dalam pencegahan kejadian nyeri bahu dan mencapai terapi nyeri bahu yang optimal terutama pada tenaga kesehatan.

\section{Metode Penelitian}

Penelitian ini merupakan penelitian analitik dengan desain penelitian potong lintang. Penelitian dilakukan dari bulan Juli sampai dengan Agustus 2019. Responden merupakan perawat yang bekerja sepenuh waktu di RS Atma Jaya dan dipilih dengan menggunakan metode simple random sampling.

Kriteria inklusi pada penelitian ini adalah responden yang bekerja sebagai perawat sepenuh waktu di RS Atma Jaya dengan usia $\leq 59$ tahun. Kriteria ekslusi pada penelitian ini adalah responden menolak berpartisipasi dalam penelitian, memiliki pekerjaan tetap lain, mempunyai riwayat trauma bahu, dan memiliki penyakit komorbid lainnya seperti diabetes mellitus, penyakit ginjal, atau penyakit organ dalam lainnya. Setiap responden yang bersedia berpartisipasi dalam penelitian diminta untuk mengisi informed consent tertulis. Setiap responden mengisi satu set kuesioner. Setiap kuesioner terdiri dari 3 bagian yang meliputi data demografis, data aktivitas dan kebiasaan yang berhubungan dengan pekerjaan, dan data gambaran karakteritik nyeri bahu yang dialami. Data demografis meliputi jenis kelamin, usia, berat badan, tinggi badan, kebiasaan melakukan pekerjaan rumah tangga, riwayat trauma, riwayat nyeri area tubuh selain bahu, dan riwayat penyakit sebelumnya. Data yang berhubungan dengan pekerjaan meliputi tempat dinas, lama bekerja, tugas shift malam, aktivitas pekerjaan dengan komputer, kebiasaan menopang atau menarik beban berat selama bekerja, dan posisi lengan selama bekerja. Data karakteristik nyeri bahu diisi jika responden pernah mengalami nyeri bahu dalam 12 bulan terakhir. Data karakteristik nyeri bahu meliputi frekuensi serangan, gangguan rentang gerak akibat nyeri, pengaruh terhadap pergerakan dan aktivitas, skala nyeri, absensi saat bekerja akibat nyeri, riwayat medikasi dan konsultasi dokter akibat nyeri bahu. Ilustrasi area nyeri bahu dicantumkan dalam kuesioner sesuai gambar 1. Pemeriksaan fisik dilakukan setelah responden mengisi informed consent dan kuesioner. Penelitian telah mendapat persetujuan etik dari komite etik FK Unika Atma Jaya dan RS Atma Jaya.

Analisis data dilakukan secara univariat dan bivariat. Analisis univariat dilakukan untuk data karakteristik dasar. Analisis bivariat dengan uji 
statistik chi square dilakukan untuk mengetahu hubungan antara variabel faktor risiko dan kejadian nyeri bahu. Selanjutnya, akan dilakukan analisis multivariat dengan menggunakan uji regresi logistik pada variabel yang memenuhi syarat nilai $p<0,25$. Hubungan antar variabel signifikan secara statistik jika $p$-value $\leq 0,05$.

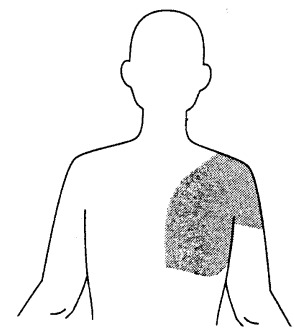

Gambar 1. Ilustrasi area nyeri bahu

\section{Hasil penelitian}

Penelitian ini melibatkan 110 responden yang memenuhi kriteria inklusi dan eksklusi dan terdiri dari 98 perawat perempuan dan 12 perawat lakilaki. Rata-rata usia responden adalah 29,6 47 tahun. Responden dalam studi ini memiliki ratarata lama bekerja 7,1 6,6 tahun.

Riwayat keluhan nyeri bahu dalam 12 bulan terakhir didapatkan pada 47,3\% responden. Usia rata-rata responden dengan nyeri bahu adalah $30,6 \pm 7,2$ tahun. Responden dengan nyeri bahu terdiri dari 46 responden perempuan $(88,5 \%)$ dan 6 pria (11,5\%). Studi menemukan 53,8\% responden mengalami 2-5 kali serangan dalam 1 tahun terakhir. Studi ini juga menemukan $57,7 \%$ responden mengeluh nyeri bahu diperberat dengan pergerakan dan $76,9 \%$ kejadian nyeri timbul setelah bekerja. Skala nyeri bahu menurut Numeric Rating Scale (NRS) memiliki rata-rata skor sebesar $3,3 \pm 1,4$. Sebagian besar nyeri bahu tidak mengganggu rentang gerak, tidak mengganggu aktivitas, dan tidak menyebabkan absensi saat bekerja. Dari studi ditemukan sebagian besar responden dengan nyeri bahu juga memiliki riwayat nyeri punggung bawah.

\begin{tabular}{lcc}
\multicolumn{3}{c}{ Tabel 2. Karakteristik nyeri bahu pada responden } \\
\hline Karakteristik & $\begin{array}{c}\text { Frekuensi } \\
\text { (n) }\end{array}$ & $\%$ \\
& & \\
\hline $\begin{array}{l}\text { Area nyeri bahu } \\
\quad \text { Kanan }\end{array}$ & 27 & 51,9 \\
$\quad$ Kiri & 25 & 48,1 \\
Durasi tiap serangan nyeri & & \\
$\quad \leq 12$ jam per hari & 44 & 84,6 \\
$\quad$ >12 jam per hari & 8 & 15,4 \\
Frekuensi serangan dalam 1 & & \\
\hline
\end{tabular}

Variabel faktor risiko nyeri bahu yang dinilai meliputi usia $>30$ tahun, lama bekerja $>5$ tahun, tempat dinas, shift malam, kebiasaan melakukan pekerjaan rumah tangga, aktivitas pekerjaan dengan menggunakan komputer, aktivitas menarik atau menopang beban dengan berat $\leq 10 \mathrm{~kg}$ dan $>10 \mathrm{~kg}$, aktivitas melakukan pekerjaan dengan posisi lengan di atas bahu, dan adanya nyeri area tubuh lain. Adanya riwayat nyeri area tubuh lain sebagai faktor risiko paling berperan terhadap kejadian nyeri bahu $(p=0,02 ; \operatorname{Exp}(B)=3,81 ; 95 \%$ IK 1,23-11,77). Beberapa faktor risiko nyeri bahu lain yang ditemukan signifikan dalam studi ini adalah usia $>30$ tahun, lama bekerja $>5$ tahun, aktivitas menarik atau menopang beban $>10 \mathrm{~kg}$, dan aktivitas dengan posisi lengan di atas bahu.

Tabel 1. Karakteristik responden penelitian

\begin{tabular}{|c|c|c|}
\hline Karakteristik & Frekuensi (n) & $\%$ \\
\hline \multicolumn{3}{|l|}{ Jenis kelamin: } \\
\hline Laki-laki & 12 & 10,9 \\
\hline Perempuan & 98 & 89,1 \\
\hline \multicolumn{3}{|l|}{ Kategori usia: } \\
\hline 21-30 tahun & 82 & 74,5 \\
\hline 31-40 tahun & 18 & 16,4 \\
\hline 41-50 tahun & 8 & 7,3 \\
\hline 51-59 tahun & 2 & 1,8 \\
\hline \multicolumn{3}{|l|}{ Shift malam } \\
\hline $\mathrm{Ya}$ & 77 & 70 \\
\hline Tidak & 33 & 30 \\
\hline \multicolumn{3}{|l|}{ Tempat dinas } \\
\hline Ruang intensif & 28 & 25,5 \\
\hline \multicolumn{3}{|l|}{$\begin{array}{l}\text { perawatan } \\
\text { bangsal dan poli } \\
\text { rawat jalan }\end{array}$} \\
\hline \multicolumn{3}{|l|}{ Lama bekerja } \\
\hline$\leq 5$ tahun & 68 & 61,8 \\
\hline$>5$ tahun & 42 & 38,2 \\
\hline \multicolumn{3}{|l|}{$\begin{array}{l}\text { Nyeri pada area } \\
\text { tubuh lain }\end{array}$} \\
\hline Ada & 85 & 77,3 \\
\hline Tidak & 25 & 22,7 \\
\hline \multicolumn{3}{|l|}{ tahun terakhir } \\
\hline 1 kali serangan & 20 & 38,5 \\
\hline 2-5 kali serangan & 28 & 53,8 \\
\hline >5 kali serangan & 4 & 7,7 \\
\hline \multicolumn{3}{|c|}{$\begin{array}{l}\text { Nyeri diperberat oleh } \\
\text { pergerakan }\end{array}$} \\
\hline $\mathrm{Ya}$ & 30 & 57,7 \\
\hline Tidak & 22 & 42,3 \\
\hline \multicolumn{3}{|c|}{ Nyeri mengganggu rentang gerak } \\
\hline $\mathrm{Ya}$ & 20 & 38,5 \\
\hline
\end{tabular}




\begin{tabular}{|c|c|c|}
\hline \multicolumn{3}{|l|}{ ARTIKEL ASLI } \\
\hline Tidak & 32 & 61,5 \\
\hline \multicolumn{3}{|l|}{ Nyeri timbul setelah bekerja } \\
\hline $\mathrm{Ya}$ & 40 & 76,9 \\
\hline Tidak & 12 & 23,1 \\
\hline \multicolumn{3}{|l|}{ Skala nyeri menurut NRS } \\
\hline $1-3$ & 34 & 65,4 \\
\hline $4-6$ & 17 & 32,7 \\
\hline $7-10$ & 1 & 1,9 \\
\hline \multicolumn{3}{|l|}{$\begin{array}{l}\text { Riwayat konsumsi obat } \\
\text { pereda nyeri }\end{array}$} \\
\hline $\mathrm{Ya}$ & 11 & 21,2 \\
\hline Tidak & 41 & 78,8 \\
\hline \multicolumn{3}{|l|}{$\begin{array}{l}\text { Riwayat konsultasi dokter } \\
\text { akibat nyeri bahu }\end{array}$} \\
\hline $\mathrm{Ya}$ & 8 & 15,4 \\
\hline Tidak & 44 & 84,6 \\
\hline \multicolumn{3}{|l|}{ Nyeri mengganggu aktivitas } \\
\hline $\mathrm{Ya}$ & 9 & 17,3 \\
\hline Tidak & 43 & 82,7 \\
\hline \multicolumn{3}{|l|}{$\begin{array}{l}\text { Riwayat tidak hadir bekerja } \\
\text { karena nyeri }\end{array}$} \\
\hline Ya & 1 & 1,9 \\
\hline Tidak & 51 & 98,1 \\
\hline \multicolumn{3}{|l|}{$\begin{array}{l}\text { Riwayat nyeri penyerta pada } \\
\text { area tubuh lain }\end{array}$} \\
\hline Nyeri punggung bawah & 27 & 51,9 \\
\hline Nyeri lutut & 5 & 9,6 \\
\hline $\begin{array}{l}\text { Nyeri tungkai bawah atau } \\
\text { kaki }\end{array}$ & 12 & 23,1 \\
\hline Tidak ada & 8 & 15,4 \\
\hline
\end{tabular}

\section{Pembahasan}

Penelitian ini menemukan terdapat keluhan nyeri bahu dalam 1 tahun terakhir pada 47,3\% populasi perawat di RS Atma Jaya. Angka kejadian yang hampir serupa ditemukan pada studi di Cina yang melaporkan prevalensi nyeri bahu pada perawat sebesar 49,66\%. ${ }^{9}$ Beberapa studi lain menemukan angka yang lebih tinggi untuk kejadian nyeri bahu atau nyeri bahu yang disertai nyeri leher yaitu sebesar 52-68,1\%.3,5,10-11 Studi pada populasi umum menemukan angka prevalensi nyeri bahu yang lebih rendah yaitu $22,9 \%$ dan $24 \% .^{12-13} \mathrm{Hal}$ ini menunjukkan populasi perawat memiliki angka insiden kejadian nyeri bahu lebih tinggi dibanding

populasi umum. Hanya $15,4 \%$ responden dengan keluhan nyeri bahu pada studi ini yang melakukan konsultasi dengan dokter. Angka ini lebih rendah daripada studi di Jepang yang menemukan 21,2\% responden melakukan konsultasi di pelayanan kesehatan. ${ }^{10} \mathrm{Hal}$ ini kemungkinan berhubungan dengan karakteristik nyeri bahu yang ditemukan dalam studi ini di mana sebagian besar responden memiliki derajat nyeri bahu yang ringan dan tidak mengeluh gangguan aktivitas atau gangguan rentang gerak akibat nyeri bahu.

Faktor risiko nyeri bahu bersifat multifaktorial yang meliputi faktor individu, fisik, psikologis, dan lingkungan. ${ }^{10-14}$ Studi ini menemukan beberapa faktor risiko terjadinya nyeri bahu pada tenaga keperawatan di RS Atma Jaya. Faktor usia, lama bekerja, riwayat nyeri area tubuh lain, aktivitas menarik atau menopang beban $>10 \mathrm{~kg}$, dan aktivitas dengan posisi lengan di atas bahu ditemukan memiliki peran signifikan terhadap terjadinya nyeri bahu pada perawat. Studi Siriwong dkk dan Munabi dkk melaporkan peningkatan risiko gangguan muskuloskeletal seiring dengan peningkatan usia dan lama bekerja. ${ }^{7,15}$ Faktor usia berhubungan dengan lama bekerja, kapasitas fisik, dan efek kumulasi paparan faktor risiko nyeri jangka panjang. ${ }^{13-16}$ Jika perawat terpapar dalam waktu lama dengan posisi dan lingkungan kerja yang tidak ergonomik, semakin besar risiko perawat tersebut untuk mengalami nyeri bahu. Faktor usia juga berhubungan dengan proses penuaan di mana pekerja dengan usia lebih tua lebih rentan mengalami cedera yang berhubungan dengan pekerjaan. ${ }^{3}$ Studi lain menemukan angka kejadian gangguan muskuloskeletal menurun pada perawat yang lebih senior baik dalam usia maupun lama bekerja. Hal ini disebabkan perawat senior lebih banyak mengerjakan tugas administratif daripada perawatan pasien, memiliki pengetahuan lebih dalam pencegahan cedera, dan mengetahui cara mengatasi masalah muskuloskeletal lebih baik daripada perawat junior. ${ }^{17}$

Tabel 3. Hubungan karakteristik data demografis, kebiasaan dan aktivitas selama bekerja dengan keiadian nveri bahu

\begin{tabular}{|c|c|c|c|c|}
\hline \multirow[t]{2}{*}{ Karakteristik } & $\begin{array}{c}\text { Ada nyeri } \\
\text { bahu }\end{array}$ & $\begin{array}{c}\text { Tidak ada nyeri } \\
\text { bahu }\end{array}$ & \multirow[t]{2}{*}{$p$} & \multirow{2}{*}{$\begin{array}{c}\text { RO } \\
(95 \% \text { IK) }\end{array}$} \\
\hline & $\mathrm{n}(\%)$ & $\mathrm{n}(\%)$ & & \\
\hline \multicolumn{5}{|l|}{ Usia } \\
\hline$>30$ tahun & $18(34,6)$ & $10(17,2)$ & $0,049^{*}$ & 2,5 \\
\hline$\leq 30$ tahun & $34(65,4)$ & $48(82,8)$ & & $(1,0-6,2)$ \\
\hline
\end{tabular}


Tabel 3. Hubungan karakteristik data demografis, kebiasaan dan aktivitas selama bekerja dengan kejadian nyeri bahu (lanjutan)

\begin{tabular}{|c|c|c|c|c|}
\hline Karakteristik & $\begin{array}{c}\begin{array}{c}\text { Ada nyeri } \\
\text { bahu }\end{array} \\
\mathrm{n}(\%) \\
\end{array}$ & $\begin{array}{c}\begin{array}{c}\text { Tidak ada nyeri } \\
\text { bahu }\end{array} \\
\mathrm{n}(\%) \\
\end{array}$ & $p$ & $\begin{array}{c}\text { RO } \\
(95 \% \text { IK })\end{array}$ \\
\hline \multicolumn{5}{|l|}{ Tempat dinas } \\
\hline Ruang intensif & $14(26,9)$ & $14(24,1)$ & \multirow{2}{*}{0,828} & 1,2 \\
\hline Ruang perawatan biasa & $38(73,1)$ & $44(75,9)$ & & $(0,5-2,7)$ \\
\hline \multicolumn{5}{|l|}{ Lama bekerja } \\
\hline$>5$ tahun & $27(51,9)$ & $15(25,9)$ & \multirow{2}{*}{$0,006^{*}$} & 3,1 \\
\hline$\leq 5$ tahun & $25(48,1)$ & $43(74,1)$ & & $(1,4-6,9)$ \\
\hline \multicolumn{5}{|l|}{ Shift malam } \\
\hline Ya & $29(55,8)$ & $48(82,8)$ & \multirow{2}{*}{$0,003^{*}$} & 0,3 \\
\hline Tidak & $23(44,2)$ & $10(17,2)$ & & $(0,1-0,6)$ \\
\hline \multicolumn{5}{|c|}{ Riwayat nyeri pada area tubuh lain } \\
\hline Ada & $47(90,4)$ & $38(65,5)$ & \multirow{2}{*}{$0,003^{*}$} & 4,9 \\
\hline Tidak & $5(9,6)$ & $20(34,5)$ & & $(1,7-14,4)$ \\
\hline \multicolumn{5}{|c|}{ Kebiasaan pekerjaan rumah tangga } \\
\hline Ya & $43(82,7)$ & $46(79,3)$ & \multirow[t]{2}{*}{0,809} & 1,2 \\
\hline Tidak & $9(17,3)$ & $12(20,7)$ & & $(0,5-3,3)$ \\
\hline \multicolumn{5}{|c|}{ Kebiasaan pekerjaan dengan komputer } \\
\hline Ya & $41(78,8)$ & $44(75,9)$ & \multirow[t]{2}{*}{0,821} & 1,2 \\
\hline Tidak & $11(21,2)$ & $14(24,1)$ & & $(0,5-2,9)$ \\
\hline \multirow{2}{*}{\multicolumn{5}{|c|}{$\begin{array}{l}\text { Aktivitas menopang atau menarik beban } \\
\leq 10 \mathrm{~kg}\end{array}$}} \\
\hline & & & & \\
\hline Ya & $34(65,4)$ & $36(62,1)$ & \multirow{2}{*}{0,843} & 1,2 \\
\hline Tidak & $18(34,6)$ & $22(37,9)$ & & $(0,5-2,5)$ \\
\hline \multicolumn{5}{|c|}{$\begin{array}{l}\text { Aktivitas menopang atau menarik beban } \\
>10 \mathrm{~kg}\end{array}$} \\
\hline $\mathrm{Ya}$ & $34(65,4)$ & $25(43,1)$ & \multirow[t]{2}{*}{$0,023^{*}$} & 2,5 \\
\hline Tidak & $18(34,6)$ & $33(56,9)$ & & $(1,2-5,4)$ \\
\hline \multicolumn{5}{|c|}{ Aktivitas dengan posisi lengan di atas bahu } \\
\hline Ya & $23(44,2)$ & $15(25,9)$ & \multirow{2}{*}{$0,048^{*}$} & 2,3 \\
\hline Tidak & $29(55,8)$ & $43(74,1)$ & & $(1,0-5,1)$ \\
\hline
\end{tabular}

IK: Interval Kepercayaan

Tabel 4. Analisis multivariat faktor risiko kejadian nyeri bahu pada perawat

\begin{tabular}{lccccccc}
\hline \multicolumn{1}{c}{ Variabel Faktor Risiko } & B & S.E. & Wald & df & Sig. & Exp(B) & 95\% C.I. \\
\hline Usia & 0,40 & 0,74 & 0,29 & 1 & 0,59 & 1,49 & $0,35-0,69$ \\
Lama bekerja & 0,80 & 0,67 & 1,46 & 1 & 0,23 & 2,23 & $0,61-8,22$ \\
$\begin{array}{l}\text { Aktivitas menopang atau } \\
\text { menarik beban >10kg }\end{array}$ & 0,78 & 0,44 & 3,13 & 1 & 0,08 & 2,19 & $0,92-5,19$ \\
$\begin{array}{l}\text { Aktivitas dengan posisi } \\
\text { lengan di atas bahu }\end{array}$ & 0,70 & 0,46 & 2,28 & 1 & 0,13 & 2,02 & $0,81-5,01$ \\
Nyeri pada area tubuh lain & 1,34 & 0,58 & 5,39 & 1 & 0,02 & 3,81 & $1,23-11,77$ \\
\hline
\end{tabular}

B: constant S.E.: Standard Error df: degrees of freedom Sig: significance Exp(B): exponentiation of the B coefficient C.I.: Confidence Interval

82 | Callosum Neurology Journal - Jurnal Berkala Neurologi Bali 
Studi ini menemukan aktivitas menarik atau menopang beban $\leq 10 \mathrm{~kg}$ tidak meningkatkan risiko nyeri bahu secara signifikan, tetapi hasil berbeda didapatkan jika beban $>10 \mathrm{~kg}$. Hasil ini didukung oleh studi Bleach dkk yang juga menemukan aktivitas menarik atau menopang beban $\geq 10 \mathrm{~kg}$ meningkatkan risiko nyeri bahu secara signifikan. ${ }^{18}$ Aktivitas menarik atau menopang beban yang dinilai dalam studi ini berkaitan dengan aktivitas responden saat melakukan perawatan pasien. Perawatan pasien merupakan kontributor nyeri muskuloskeletal khususnya area punggung bawah, leher, dan bahu. ${ }^{2,5,7}$ Perawatan pasien meliputi aktivitas mengganti posisi pasien saat berada di ranjang, membantu pasien berpindah posisi, memandikan atau mengganti baju pasien, mengangkat pasien, menarik atau mendorong ranjang atau kursi roda saat transfer pasien, dan memindahkan pasien dari dan ke kursi roda atau ranjang. ${ }^{4,6,19}$ Studi Smedley dkk menunjukkan peningkatan risiko nyeri leher atau bahu saat melakukan aktivitas memindahkan pasien dari dan ke kursi roda atau ranjang serta saat memandikan atau mengganti baju pasien. Peningkatan risiko terjadi seiring dengan peningkatan jumlah aktivitas yang dilakukan perawat dalam 1 shift. ${ }^{6}$

Aktvitas dengan posisi lengan di atas bahu juga ditemukan meningkatkan risiko terjadi nyeri bahu pada perawat dalam studi ini.Hasil ini didukung oleh hasil beberapa studi yang menemukan posisi lengan di atas bahu dapat meningkatkan risiko terjadi nyeri bahu pada perawat. ${ }^{14,18,20}$ Bekerja dengan posisi canggung dan pergerakan berulang area bahu, tangan, atau pergelangan tangan meningkatkan risiko terjadi gangguan bahu. ${ }^{17,18-21}$ Mempertahankan bahu dalam posisi abduksi dapat mencetuskan iskemi parsial pada pembuluh darah yang memperdarahi tendon dan struktur lainnya. Jika hal ini terjadi terus-menerus, dapat terjadi cedera minor pada area otot dan tendon. ${ }^{22}$

Adanya nyeri area muskuloskeletal lain ditemukan sebagai faktor risiko paling berperan dalam terjadinya nyeri bahu pada perawat. Studi lizuka dkk juga menemukan prevalensi nyeri leher dan bahu meningkat pada responden dengan nyeri area lumbar, lutut, dan siku/pergelangan tangan. ${ }^{10}$ Studi Smedley dkk melaporkan insiden nyeri leher/bahu yang tinggi pada perawat dengan riwayat nyeri leher/bahu dan punggung bawah sebelumnya dengan durasi $>4$ minggu. ${ }^{6} \mathrm{Hal}$ ini kemungkinan berhubungan dengan ambang batas nyeri yang berbeda-beda pada setiap individu, di mana individu dengan nyeri muskuloskeletal dapat memiliki ambang batas nyeri lebih rendah. ${ }^{10}$
Riwayat nyeri bahu dan leher merupakan prediktor terkuat terjadinya gejala nyeri bahu dan leher di masa depan. ${ }^{6}$ Tidak adanya riwayat gangguan muskuloskeletal dapat menjadi faktor protektif terhadap gangguan muskuloskeletal. ${ }^{9}$

Studi ini menunjukkan shift malam menjadi faktor protektif terhadap kejadian nyeri bahu. Peneliti menduga hal ini disebabkan beberapa hal antara lain: sebagian besar perawat yang bertugas shift malam di rumah sakit tempat penelitian dilakukan adalah perawat junior yang berusia lebih muda; pekerjaan seperti memandikan pasien, mengganti alas ranjang pasien, mendorong pasien saat di kursi roda atau ranjang ke ruangan pemeriksaan lain biasanya dilakukan oleh perawat shift pagi sehingga perawat lebih tidak terpapar aktivitas yang memiliki risiko terjadinya nyeri bahu saat shift malam. Namun hasil berbeda ditemukan pada studi Ping Yan dkk dan Abedini dkk di mana faktor bekerja shift malam berpengaruh signifikan pada kejadian nyeri bahu. ${ }^{9,19}$ Hasil berbeda ini dapat disebabkan perbedaan tugas, beban kerja, dan jumlah perawat saat shift malam di rumah sakit tempat penelitian dilakukan. Penelitian lebih lanjut perlu dilakukan pada populasi perawat dengan distribusi karakteristik tugas, beban kerja, dan jumlah perawat saat shift pagi dan malam yang lebih merata.

Penggunaan komputer tidak ditemukan sebagai faktor risiko signifikan dalam studi ini. Hasil ini dapat disebabkan penggunaan komputer bukan merupakan aktivitas yang dominan dilakukan pada perawat sehingga penggunaan komputer tidak menjadi faktor risiko signifikan nyeri bahu pada populasi ini. Studi ini menemukan persentase nyeri bahu lebih besar pada responden yang bekerja di ruang intensif namun tidak berbeda signifikan secara statistik. Hasil studi ini berbeda dengan studi di Cina di mana prevalensi tertinggi ditemukan di ruang emergensi. Studi di Iran menemukan frekuensi gangguan muskuloskeletal paling tinggi didapatkan pada responden yang bekerja di ruangan intensif di mana mereka harus mengangkat pasien yang tidak mampu menopang tubuhnya sendiri. ${ }^{2,9}$ Hasil yang berbeda ini dapat disebabkan adanya rasio perawat-jumlah pasien yang lebih rendah di ruang perawatan biasa di RS Atma Jaya. Berdasarkan hasil studi, beban pasien yang berlebihan dalam 1 hari dapat menjadi faktor risiko gangguan muskuloskeletal. ${ }^{2,17,19}$

Keterbatasan dari penelitian dengan desain crosssectional ini adalah tidak dapat menggambarkan hubungan sebab-akibat secara langsung antara variabel faktor risiko dan kejadian nyeri bahu. 
Walaupun terdapat keterbatasan, hasil penelitian ini diharapkan dapat membantu dalam penyusunan program kerja untuk mencegah terjadinya gangguan muskuloskeletal khususnya nyeri bahu yang berhubungan dengan pekerjaan pada perawat. Sebagai contoh, program pelatihan yang adekuat untuk meningkatkan pengetahuan dan skill perawat dalam perawatan pasien serta program sederhana seperti restriksi mengangkat beban di atas bahu direkomendasikan untuk mengurangi kejadian gangguan muskuloskeletal yang berkaitan dengan pekerjaan. ${ }^{18-19}$

\section{Simpulan}

Prevalensi nyeri bahu pada perawat adalah sebesar $47,3 \%$. Studi ini menemukan adanya nyeri area

\section{Daftar Rujukan}

1. Harcombe H, Herbison GP, McBride D, Derrett S. Musculoskeletal disorders among nurses compared with two other occupational groups. Occupational Medicine. 2014;64(8):601-7.

2. Akbari $\mathrm{H}$, Akbari $\mathrm{H}$, Abadi $\mathrm{MBH}$, Fesharaki MG, Ghasemi M. Assessing the risk of manual handling of patients and its relationship with the prevalence of musculoskeletal disorders among nursing staff: Performance evaluation of the MAPO and PTAI methods. Iran Red Crescent Med J. 2017;19(2):e39860.

3. Santos ECD, Andrade RD, Lopes SGR, Valgas C. Prevalence of musculoskeletal pain in nursing professionals working in orthopedic setting. Revista Dor. 2017:18(4):298-306.

4. Ellapen TJ, Narsigan S. Work related musculoskeletal disorders among nurses: systematic review. Journal of Ergonomics. 2015;S4:S4-003.

5. Moreira RFC, Sato TO, Foltran FA, Silva LCCB, Coury HJCG. Prevalence of musculoskeletal symptoms in hospital nurse technicians and licensed practical nurses: associations with demographic factors. Braz J Phys Ther. 2014 July-Aug;18(4):323-33.

6. Smedley J, Inskip H, Trevelyan F, Buckle $P$, Cooper C, Coggon D. Risk factors for incident neck and shoulder pain in hospital nurses. Occupational and Environmental Medicine. 2003;60(11):864-69.

7. Munabi IG, Buwembo W, Kitara DL, Ochieng J, Mwaka ES. Musculoskeletal disorder risk factors among nursing professionals in low resource settings: A cross-sectional study in Uganda. BMC Nursing. 2014;13(1):7. tubuh lain berhubungan dengan terjadinya nyeri bahu pada perawat. Beberapa faktor lain yang berhubungan dengan terjadinya nyeri bahu pada perawat, yaitu: usia $>30$ tahun, lama bekerja $>5$ tahun, aktivitas menarik atau menopang beban $>10 \mathrm{~kg}$, dan aktivitas bekerja dengan posisi lengan di atas bahu.

\section{Pengakuan}

Peneliti mengucapkan terimakasih kepada pihak Rumah Sakit Atma Jaya dan seluruh perawat yang terlibat dalam membantu penelitian ini.

\section{Konflik Kepentingan}

Peneliti tidak memiliki konflik kepentingan dalam publikasi artikel ini.

8. Kooienga SA, Rasmor M. Shoulder pain assessment for the occupational health nurse. Workplace Health \& Safety. 2016;64(10):44852.

9. Yan $P$, Li F, Zhang $L$, Yang $Y$, Huang $A$, Wang $Y$, Yao $H$. Prevalence of work-related musculoskeletal disorders in the nurses working in Hospitals of Xinjiang Uygur Autonomous Region. Pain Research and Management. 2017;1-7.

10. lizuka $Y$, Shinozaki $T$, Kobayashi $T$, et al. Characteristics of neck and shoulder pain (called katakori in Japanese) among members of the nursing staff. Journal of Orthopaedic Science. 2012;17(1):46-50.

11. Genç A, Kahraman T, Göz E. The prevalence differences of musculoskeletal problems and related physical workload among hospital staff. Journal of Back and Musculoskeletal Rehabilitation. 2016;29(3):541-47.

12. Bhawna, Multani NK, Kundu ZS. Prevalence of shoulder pain among adults in Northern India.Asian Journal of Health and Medical Research. 2016;2(2):18-22.

13. Bento TPF, Genebra CVS, Cornélio GP, et al. Prevalence and factors associated with shoulder pain in the general population: $A$ cross-sectional study. Fisioter. 2019;29(4):401-6.

14. Yang S, Lu J, Zeng J, Wang L, Li Y. Prevalence and risk factors of work-related musculoskeletal disorders among intensive care unit nurses in China. Workplace Health \& Safety. 2019 Jun;67(6):275-87.

15. Siriwong $W$, Chanchail W, Songkham W, Ketsomporn P, Sappakitchanchai P. Effects of 
physical and psychosocial work environment factors on musculoskeletal symptoms among hospital orderlies at a tertiary care hospital. EC Orthopaedics. 2017;7(2):47-56.

16. Jellad A, Lajili $H$, Boudokhane $S$, Migaou $H$, Maatallah S, Frih ZBS. Musculoskeletal disorders among Tunisian hospital staff: Prevalence and risk factors. The Egyptian Rheumatologist. 2013;35(2):59-63.

17. Tinubu BM, Mbada CE, Oyeyemi AL, et al. Work-related musculoskeletal disorders among nurses in ibadan, south-west nigeria: A cross-sectional survey. BMC Musculoskelet Disord. 2010;11:12.

18. Beach J, Senthilselvan A, Cherry N. Factors affecting work-related shoulder pain. Occupational Medicine. 2012;62(6):451-54.

19. Abedini $R$, Choobineh AR, Hasanzadeh J. Patient manual handling risk assessment among hospital

nurses.

Work. 2015;50(4):669-75.

20. van Rijn RM, Huisstede BMA, Koes BW, Burdorf A. Associations between work-related factors and specific disorders of the shoulder - a systematic review of the literature. Scand J Work Environ Health. 2010;36(3):189-201.

21. Anap DB, lyer C, Rao K.Work related musculoskeletal disorders among hospital nurses in rural Maharashtra, India: A multi centre survey. Anap DB et al. Int J Res Med Sci. 2013 May;1(2):101-7.

22. Magnago TS, Lisboa MT, Griep RH, Kirchhof AL, De Azevedo Guido L. Psychosocial aspects of work and musculoskeletal disorders in nursing workers. Rev Lat Am Enfermagem. 2010 May-Jun;18(3):429-35. 